Info Artikel:

Diterima: 07/11/2015

Direvisi: 29/11/2015

Dipublikasikan: 30/12/2015

Indonesian Institute for Counseling, Education and Therapy (IICET)

\title{
Meningkatkan Keterampilan Berbicara Siswa dengan Media Gambar Seri
}

\author{
Noni Risnawelli \\ SDN 18 Batang Anai Kabupaten Padang Pariaman
}

\begin{abstract}
Abstrak
Result of initial observation at SDN 18 Batang Anai Kabupaten Padang Pariaman indicated that 1 st grade students were afraid and shy to speak in front of class. It was caused the language learning only emphasized on reading and writing skills. Speaking skill was still not being a main focus. This is a classroom action research aimed to improve students' speaking skill. Data were colected by using test and observation. In cycle I, percentage of students' speaking skill mean score is $53,3 \%$. In cycle II, percentage of students' speaking skill mean score is $86 \%$. Hence, learning with media of picture-series can improve students' speaking skill.
\end{abstract}

Kata Kunci: speaking skill, media of picture-series, bahasa

This is an open access article distributed under the Creative Commons Attribution License, which permits unrestricted use, distribution, and reproduction in any medium, provided the original work is properly cited. (C2017 by author and Indonesian Institute for Counseling, Education and Therapy (IICET).

\section{PENDAHULUAN}

Dalam Kurikulum Tingkat Satuan Pendidikan (KTSP) 2006 bahasa Indonesia, pada rambu pertama dijelaskan bahwa tujuan pembelajaran bahasa Indonesia adalah mampu berkomunikasi secara efektif dan efesien sesuai dengan etika yang berlaku baik secara lisan maupun tulis. Berpedoman pada isi KTSP tersebut, tujuan pembelajaran bahasa Indonesia bukan hanya menjadikan siswa memiliki pengetahuan tentang bahasa Indonesia, tetapi bertujuan agar siswa terampil berbahasa untuk berkomunikasi lisan mencakup keterampilan berbicara dan menyimak. Pembelajaran berbahasa Indonesia mencakup empat aspek keterampilan berbahasa yaitu keterampilan menyimak, keterampilan berbicara, keterampilan membaca dan keterampilan menulis. Satu keterampilan berbahasa saling terkait dengan keterampilan berbahasa lainya (Tarigan, 1988). Dalam penulisan ini peneliti menfokuskan pada keterampilan berbicara. Menurut Brown (dalam Ratu dkk, 2005), keterampilan berbicara diartikan keterampilan mengucapkan bunyi-bunyi bahasa untuk mengekspresikan atau menyampaikan pikiran, gagasan atau perasaan secara lisan.

Berbicara adalah berkata, bercakap, berbahasa atau melahirkan pendapat dengan perkataan, tulisan dan sebagainya atau berunding (Kridalaksana, 1996). Kemampuan berbicara perlu dimiliki setiap orang, kemampuan ini tidak di dapat secara turun temurun melainkan melalui latihan dan bimbingan yang teratur. Tujuan berbicara dapat dibagi atas tujuan umum dan tujuan khusus. Tujuan umum adalah tujuan yang ingin dicapai seseorang untuk menyampaikan pikiran dan perasaan kepada orang lain, sedangkan tujuan khusus merupakan suatu hal yang diharapkan untuk dikerjakan, dirasakan, diyakini, dimengerti, atau disenangi oleh pendengar (Lana, 1988). Berbicara bertujuan melatih siswa supaya melahirkan perasaan dan pikirannya dengan teratur, sedangkan guru berperan memimpin dan memberikan 
Jurnal Penelitian Pendidikan Indonesia

Jurnal Pendidikan Indonesia
Volume 1 Nomor 1 Desember 2015, hlm 27-35

Akses Online: http://jurnal.iicet.org

petunjuk- petunjuk seperlunya (Sanjaya, 2006). Tujuan berbicara itu melatih siswa melahirkan isi hatinya (pikiran, perasaan, dan kemauannya) secara lisan dengan kalimat yang teratur dan kalimat yang baik, memperbesar dorongan batin akan melahirkan isi hatinya, memupuk keberanian berbicara pada siswa, menambah perbendarahan bahasa siswa memberikan kesempatan pada siswa untuk menyatakan dirinya (jika di tinjau dari psikologis humanisnya). Tujuan di atas lebih menspesifikasikan tujuan berbicara pada Sekolah Dasar sesuai dengan harapan kurikulum.

Berdasarkan pengalaman mengajar peneliti pada siswa kelas I SDN 18 Batang Anai Kabupaten Padang Pariaman, terungkap bahwa siswa belum terampil berbicara (kurang lancar, merasa malu dan takut). Kemudian peneliti berwawancara dengan kepala sekolah, ternyata pembelajaran keterampilan berbicara yang selama ini dilakukan hanya sebatas bertanya jawab dengan siswa dan meminta beberapa orang siswa untuk bercerita di depan kelas. Akibatnya tidak semua siswa berani untuk berbicara di depan kelas. Hal ini disebabkan kurangnya kreatifitas guru dalam merancang dan menyajikan pembelajaran. Dapat dilihat pada penggunaan media yang tidak ada sama sekali, hingga berimbas pada hasil belajar siswa yang tidak mencapai target sesuai dengan tujuan dari pembelajaran bahasa Indonesia seperti yang diamanatkan dalam kurikulum.

Salah satu upaya yang bisa digunakan untuk mengatasi masalah tersebut guru harus kreatif dalam melaksanakan proses pembelajaran. Hal ini dapat dilakukan dengan berbagai cara, salah satunya adalah dengan menggunakan media yang sesuai dengan tujuan pembelajaran, jenis tugas, dan respon yang diharapkan dikuasai siswa setelah pembelajaran berlangsung, dan konteks pembelajaran termasuk karakteristik siswa. Manfaat media dalam proses pembelajaran adalah dapat membangkitkan keingin tahuan dan minat siswa yang baru, membangkitkan motivasi dan rangsangan kegiatan belajar, dan bahkan membawa pengaruh-pengaruh psikologis terhadap siswa. Meskipun demikian, dapat dikatakan bahwa salah salah satu fungsi utama media pembelajaran adalah sebagai alat bantu pembelajaran yang turut mempengaruhi iklim, kondisi, dan lingkungan belajar yang ditata dan diciptakan oleh guru. Selain menyajikan materi pembelajaran, guru juga hendaknya jeli dalam menentukan media pembelajaran yang akan digunakan, sebab media pembelajaran terbagi dalam beberapa macam yang penggunaannya disesuaikan dengan materi pembelajaran dan karakteristik siswa.

Pemilihan dan penggunaan media yang tepat tentunya akan memaksimalkan hasil belajar siswa dan sesuai dengan yang diharapkan. Pada penelitian ini, media gambar berseri dipilih sebagai solusi. Gambar seri adalah kumpulan dari beberapa gambar yang menceritakan suatu kejadian atau peristiwa yang menarik yang disusun secara acak, atau berurut untuk dijadikan sebuah cerita (Arsyad, 2003). Sedangkan menurut Sudiman (2003) yang di maksud dengan gambar seri adalah rangkaian beberapa gambar yang saling berkaitan yang membuat sebuah cerita. Keefektifan penggunaan alat bantu gambar dalam proses pembelajaran adalah sebagai berikut: 1) gambar merupakan perangkat pengajaran yang dapat menarik minat siswa, 2) gambar harus dikaitkan dengan kehidupan nyata, agar minat siswa menjadi efektif, dan 3) gambar membantu para siswa membaca buku pelajaran terutama dalam menafsirkan dan mengingat-ingat isi teks yang menyertainya. Penggunaan gambar seri dalam proses pembelajaran akan dapat menfokuskan perhatian siswa terhadap pembelajaran sehingga tidak membosankan dan dapat meningkatkan hasil belajar. Gambar seri juga dapat menarik minat siswa untuk mengungkapkan ide atau gagasan dalam bentuk lisan.

\section{METODE}

Penelitian ini dilaksanakan di SDN 18 Batang Anai Kabupaten Padang Pariama. Alasan dipilihnya lokasi ini adalah karena siswa kelas IB di SDN 18 Batang Anai Kabupaten Padang Pariaman belum maksimal dalam pembelajaran keterampilan berbicara. Selain itu, peneliti juga bertugas di sekolah ini yang mengajar di kelas IB. Subjek dalam penelitian adalah siswa di kelas IB di SDN 18 Batang Anai Kabupaten Padang Pariaman yang berjumlah 30 orang. Jenis penelitian yang digunakan dalam pelaksanaan penelitian di lapangan adalah penelitian tindakan kelas, karena penelitian tindakan kelas ini sangat cocok dalam penelitian ini. Keadaan yang ada di lapangan selama proses pembelajaran tidak 
Jurnal Penelitian Pendidikan Indonesia

Jurnal Pendidikan Indonesia
Volume 1 Nomor 1 Desember 2015, hlm 27-35

Akses Online: http://jurnal.iicet.org

dikondisikan, tetapi sesuai dengan kegiatan yang ada. Jenis penilitiaan ini merupakan penelitian tindakan kelas karena kajiannya bersifat reflektif. Refleksi dilakukan untuk meningkatkan kemantapan rasional serta memperdalam pemahaman dan memperbaiki tindakan-tindakan dalam proses pembelajaran. Rangkaian langkah terdiri dari studi pendahuluan, refleksi awal, perencanaan, pelaksaan, pengamatan, dan refleksi. Data dikumpulkan melalui tes dan observasi.

\section{HASIL}

\section{Deskripsi Siklus I}

\section{Perencanaan}

Perencanaan tindakan dibuat berdasarkan waktu yang telah disepakati antara peneliti, kepala sekolah sebagai pengamat dalam penelitian ini. Standar kompetensi yang peneliti gunakan adalah keterampilan berbicara, yaitu mengungkapkan pikiran, perasaan dan informasi secara lisan dengan gambar, percakapan sederhana dan dongeng. Kompetensi dasar yang harus dikuasai siswa adalah menjelaskan isi gambar tunggal atau gambar seri sederhana dengan bahasa yang mudah dimengerti. Indikator yang akan dicapai oleh siswa dalam proses pembelajaran adalah sebagai berikut: (1) menyebutkan peristiwa-peristiwa yang terdapat dalam setiap gambar seri, (2) mengurutkan gambar seri sesuai urutan yang benar, (3) menentukan judul media gambar seri, (4) menceritakan gambar seri dengan bahasa sendiri dengan lafal, intonasi dan ekspresi yang tepat.

\section{Pelaksanaan}

Pelaksanaan proses pembelajaran keterampilan berbicara melalui media gambar seri dibagi menjadi tiga, yaitu kegiatan awal, kegiatan inti, kegiatan akhir. Dari gambaran proses pembelajaran yang telah berlangsung tersebut dapat disimpulkan bahwa siswa cukup mempunyai keberanian dalam mengemukakan pendapat dan idenya dalam menjawab pertanyaan-pertanyaan yang diberikan oleh guru. Begitupun dalam proses pemberian judul pada media gambar seri siswa sangat aktif dan berani dalam menjawab pertanyaan yang diajukan oleh guru. Kondisi ini terbukti dengan banyaknya anak yang menunjuk tangan ketika diberi pertanyaan oleh guru. Hampir semua siswa berani maju ke depan kelas untuk bercerita walaupun tidak semua bisa dan lancar dalam menceritakan media gambar seri dan bahkan ada beberapa orang siswa hanya diam saat tiba di depan kelas. Peneliti sebagai guru dalam proses pembelajaran ini memotivasi siswa dengan mengajukan beberapa pertanyaan yang berkaitan dengan media gambar seri agar siswa bisa menceritakan media gambar seri.

Aktivitas selanjutnya adalah meminta tanggapan siswa tentang media gambar yang telah diceritakan dengan bahasa sendiri dengan menggunakan lafal, intonasi dan ekspresi yang sesuai berlangsung secara baik. Hal ini terwujud saat siswa memberikan tanggapan tentang isi cerita. Penilaian dilakukan saat siswa memberikan tanggapan tentang isi cerita berdasarkan alasan yang logis dan sesuai dengan isi cerita. Kegiatan ini berlangsung selama lebih kurang tiga puluh menit. Kegiatan akhir proses pembelajaran keterampilan berbicara yang dilakukan pada pertemuan ini adalah menyampaikan pesan-pesan moral dan membimbing siswa menyimpulkan pembelajaran serta motivasi siswa untuk lebih meningkatkan keterampilan berbicara.

\section{Pengamatan}

Pengamatan keberhasilan tindakan proses pembelajaran diamati selama dan sesudah tindakan dilaksanakan. Kegiatan ini dilakukan oleh observer kepala sekolah sebagai pengamat. Pengamat tugasnya mengamati kegiatan yang dilakukan oleh guru, mengamati aspek kegiatan siswa. Hal ini dilaksanakan untuk mendapatkan informasi dari guru, siswa, dan pengamat terhadap pelaksanaan proses pembelajaran yang berlangsung pada siklus I. Guru cukup berhasil dalam melaksanakan proses pembelajaran. Hanya saja guru agak kedodoran dalam masalah waktu. Hal ini terjadi pada masing-masing kegiatan proses pembelajaran. Kelebihan waktu tersebut berkisar antara lima belas sampai dua puluh menit untuk masing-masing kegiatan proses pembelajaran. Namun guru senang 
Jurnal Penelitian Pendidikan Indonesia

Jurnal Pendidikan Indonesia
Volume 1 Nomor 1 Desember 2015, hlm 27-35

Akses Online: http://jurnal.iicet.org

dengan penelitian ini karena setiap siswa sudah mulai berani bercerita ke depan kelas secara khusus dan lebih berani dalam berbicara secara umum.

Siswa aktif menjawab bahkan mengajukan pertanyaan saat guru mulai pada pembelajaran selanjutnya akan tetapi masih banyak juga siswa yang hanya diam saat peneliti mencoba mengajukan pertanyaan pada siswa. Hal ini disebabkan kurang motivasi dari peneliti. Beranjak dari masalah di atas, peneliti mencoba memberi motivasi dan membuat siswa agar tertarik dan berani untuk berbicara yaitu dengan cara memajangkan media gambar seri yang telah disiapkan sebelumnya. Penilaian hasil pada proses pembelajaran keterampilan berbicara melalui media gambar seri meliputi kemampuan menjawab pertanyaaan, kelancaran membaca karangan, kerapian tulisan, dan penggunaan tanda baca. Penilaian hasil pembelajaran berbicara pada siklus I ini lebih dirinci berdasarkan rata-rata sebagai berikut: (1) mampu menjawab pertanyaan 3,2\%, (2) kelancaran membaca karangan 3,0\%, (3) kerapian tulisan 2,9\%, (4) penggunaan tanda baca 2,7\%. Namun, pada saat siswa tampil ke depan kelas untuk bercerita melalui media gambar seri masih ada sebahagian siswa tidak bisa bercerita bila tidak dibimbing melalui pertanyaan yang berkaitan dengan gambar. Saat itu guru menunjuk media gambar seri sambil mengajukan beberapa pertanyaan yang bisa memotivasi siswa dalam bercerita melalui media gambar seri di mana hal itu dilakukan oleh guru sesuai dengan tujuan pembelajaran yang ingin dicapai, yaitu untuk meningkatkan keterampilan berbicara melalui media gambar seri.

Penilaian yang menyeluruh terhadap kegiatan proses pembelajaran berbicara melalui media gambar seri ini meliputi penilaian proses dan penilaian hasil. Penilaian tersebut lebih dirinci berdasarkan rata-rata sebagai berikut: (1) penilaian proses $11,8 \%$, dan (2) penilaian hasil $11,9 \%$. Data-data tersebut memberi gambaran bahwa dari empat aspek yang dinilai ada satu aspek yang memperoleh nilai kurang yaitu aspek keberhasilan siswa dalam mengikuti seluruh kegiatan proses pembelajaran berbicara melalui media gambar seri pada siklus I adalah 11,9\%.

\section{Refleksi}

Kegiatan refleksi dilakukan secara kolaboratif antara peneliti dengan pengamat di setiap akhir proses pembelajaran berlangsung. Berdasarkan hasil kolaborasi menunjukan bahwa pelaksanaan pembelajaran melalui media gambar seri sudah terlaksana oleh guru sesuai dengan langkahlangkah pembelajaran yang tercantum dalam RPP. Terlaksananya kegiatan proses pembelajaran merupakan implikasi dari pengunaan media yang menarik bagi siswa. Proses pembelajaran pada siklus I ini mengalami kendala dalam mengatasi keributan yang di karenakan jumlah siswa yang lumayan banyak yaitu 30 orang siswa dalam satu kelas tapi hal ini dapat di atasi dengan menerapkan metode belajar yang menyenangkan salah satunya dengan media gambar seri yang menarik dan ketika siswa sudah mulai jenuh maka peneliti sebagai guru meminta siswa menyanyikan salah satu lagu yang disukai.

Pada kegiatan proses pembelajaran, hasil pengamatan yang dilakukan kepala sekolah selaku pengamat terhadap peneliti, langkah-langkah yang dilakukan peneliti sudah sesuai dengan perencanaan. Hasil pengamatan sudah mencapai hasil cukup baik. Guru sudah melakukan langkah-langkah pembelajaran sesuai dengan RPP. Hasil pengamatan dari pengamat dalam mengamati aktivitas siswa selama kegiatan pembelajaran belum maksimal. Hal ini disebabkan karena siswa belum faham terhadap langkah-langkah pembelajaran yang disebutkan oleh guru, ini terlihat banyak siswa yang bingung ketika siswa disuruh kedepan kelas untuk menceritakan media gambar seri.

Penilaian berbicara di fokuskan pada penilaian proses dan penilaian hasil. Penilain proses pembelajaran keterampilan berbicara melalui media gambar seri yaitu: keberanian siswa dalam bercerita, kelancaran dalam bercerita, kesesuaiaan isi cerita dengan gambar, dan lafal dan intonasi. Sementara penilaian hasil yaitu: kemampuan menjawab pertanyaan, kelancaran membaca karangan, kerapian tulisan, penggunaan tanda baca. Saat siswa tampil ke depan kelas untuk 
Jurnal Penelitian Pendidikan Indonesia

Jurnal Pendidikan Indonesia
Volume 1 Nomor 1 Desember 2015, hlm 27-35

Akses Online: http://jurnal.iicet.org

bercerita ada beberapa orang siswa yang hanya diam maka peran peneliti sebagai guru adalah memotivasi siswa dengan mengajukan pertanyaan-pertanyaan yang berkaitan dengan gambar agar siswa tersebut dapat menceritakan gambar melalui media gambar seri. Apabila jawaban siswa tidak sesuai dengan media gambar maka disini guru meminta siswa untuk kembali mengamati media gambar seri yang ada dan guru kembali mengajukan pertanyaan yang sama kepada siswa. Sedangkan kegiatan akhir dilakukan dengan meminta siswa menanggapi cerita yang telah didengar dan penyampaian pesan-pesan moral, dan membimbing siswa menyimpulkan pembelajaran. Refleksi yang dilakukan pada siklus selanjutnya akan memberikan penekanan kepada siswa agar mampu menceritakan media gambar seri dengan bahasa sendiri dengan lafal dan intonasi yang sesuai.

\section{Deskripsi Siklus II}

1. Perencanaan

Peneliti bersama kepala sekolah yang bertindak sebagai pengamat membuat perencanaan siklus II secara kolaboratif. Perencanan tindakan dibuat dalam bentuk RPP.

\section{Pelaksanaan}

Hampir semua siswa berani maju ke depan kelas untuk bercerita walaupun tidak semua lancar dalam menceritakan media gambar seri ada beberapa orang siswa yang hanya menceritakan pointpoint tiap gambar seri, hal ini bisa diatasi guru dengan menunjuk pada tiap-tiap gambar seri sesuai urutannya sehingga siswa bisa bercerita sesuai dengan media gambar yang ada dengan urutan yang benar. Kegiatan ini dilakukan selama lebih kurang enam puluh menit dalam langkah mencapai indikator yang telah dirumuskan sebelumnya. Selanjutnya proses pembelajaran meminta tanggapan siswa tentang isi cerita gambar seri yang telah di ceritakan melalui bimbingan dengan pertanyaan. Kegiatan meminta tanggapan siswa tentang cerita yang telah di ceritakan dengan bahasa sendiri dengan menggunakan lafal dan intonasi yang sesuai berlangsung secara baik. Hal ini terwujud saat siswa memberikan tanggapan tentang isi cerita. Penilaiaan dilakukan saat siswa memberikan jawaban dari pertanyaan yang diajukan dan memberikan tanggapan yang sesuai dengan gambar. Kegiatan ini berlangsung selama lebih kurang lima belas menit. Kegiatan akhir proses pembelajaran keterampilan berbicara yang dilakukan adalah menyampaikan pesan-pesan moral oleh guru dan membimbing siswa menyimpulkan pembelajaran serta motivasi siswa untuk lebih meningkatkan keterampilan berbicara.

\section{Pengamatan}

Pengamatan keberhasilan tindakan proses pembelajaran diamati selama dan sesudah tindakan dilaksanakan. Kegiatan ini dilaksanakan untuk mendapatkan informasi dari siswa, guru, dan pengamat terhadap pelaksaan proses pembelajaran yang berlangsung pada siklus II. Untuk mengamati aktivitas guru dilakukan oleh kepala sekolah selaku pengamat dan mengamati aktivitas siswa dengan menggunakan lembar observasi. Pada tahap ini kegiatan yang dilakukan oleh pengamat adalah mengamati jalannya proses pembelajaran keterampilan berbicara melalui media gambar seri. Pelaksanaan proses pembelajaran dari aspek siswa sudah terlaksana dengan baik sesuai dengan RPP, hal ini terlihat dari keaktifan siswa pada setiap langkah-langkah pembelajaran. Selanjutnya semua siswa aktif menjawab bahkan mengajukan pertanyaan saat guru mulai pada pembelajaran selanjutnya akan tetapi masih ada beberapa orang siswa yang hanya diam saat peneliti mencoba mengajukan pertanyaan pada siswa. Hal ini disebabkan kurang motivasi dari peneliti dan siswa tersebut memeng sangat pemalu untuk berbicara. Beranjak dari masalah diatas, peneliti mencoba memberi motivasi dan membuat siswa agar tertarik dan berani untuk berbicara yaitu dengan cara memajangkan media gambar seri yang telah disiapkan sebelumnya.

Data penilaian pada proses pembelajaran keterampilan berbicara melalui media gambar seri terdiri dari penilaian proses dan penilaian hasil. Penilaian proses terdiri dari yaitu aspek keterampilan berbicara yakni: keberaniaan siswa dalam bercerita, kelancaran, kesesuaian isi cerita dengan gambar, dan lafal/intonasi. Penilaian proses keterampilan berbicara siswa pada siklus II ini 
Jurnal Penelitian Pendidikan Indonesia

Jurnal Pendidikan Indonesia
Volume 1 Nomor 1 Desember 2015, hlm 27-35

Akses Online: http://jurnal.iicet.org

lebih dirinci berdasarkan rata-rata sebagai berikut yaitu: (1) keranian dalam bercerita 3,7\%, (2) kelancaran dalam bercerita 3,2\%, (3) kesesuaian isi cerita dengan gambar 3,1\%, (4) lafal dan intonasi $3,2 \%$. Keberhasilan siswa dalam proses pembelajaran ini sebesar $13,2 \%$. Keberhasilan ini berada dalam taraf baik. Hasil pembelajaran berbicara melalui media gambar seri adalah sebagai berikut: nilai tertinggi pada siklus II adalah 16 dan nilai terendah adalah 10,5. Dari data rekapitulasi penilaian proses dan penilaian hasil persentase ketuntasan yang diperoleh adalah $86 \%$ dan yang tidak tuntas adalah $13 \%$ dengan 26 orang siswa yang tuntas dan 4 orang siswa yang tidak tuntas. Berdasarkan data tersebut dapat disimpulkan bahwa pembelajaran pada siklus II mengalami peningkatan jika dibandingkan dari siklus I dan penilaian yang di capai pada siklus II adalah $86 \%$ sudah mencapai ketuntasan. Dimana sudah melebihi ketuntasan yang ditetapkan, yaitu $75 \%$.

\section{Refleksi}

Kegiatan refleksi dilakukan secara kolaboratif antara peneliti dengan pengamat di setiap akhir proses pembelajaran. Pada kesempatan ini temuan dan hasil pengamatan peneliti dibahas bersama. Refleksi tindakan siklus II ini mencakup refleksi terhadap perencanaan, pelaksanaan, dan penilaian yang di peroleh oleh siswa. Berdasarkan hasil pengamatan dan pencatatan lapangan siklus II sudah terlaksana dengan baik. Pelaksanaan pembelajaran melalui media gambar seri sudah terlaksana oleh guru sesuai dengan langkah-langkah pembelajaran yang tercantum dalam RPP. Proses pembelajaran pada siklus I ini mengalami kendala mengatasi keributan yang di karenakan jumlah siswa yang banyak, yaitu 30 siswa dalam satu kelas, tapi hal ini dapat di atasi dengan menerapkan metode belajar yang menyenangkan salah satunya dengan media gambar seri yang menarik dan belajar sambil diselingi dengan bernyanyi di saat siswa merasa jenuh.

Penilaian berbicara difokuskan pada penilaian proses dan penilaian hasil. Dimana penilaian proses, yaitu keberanian siswa dalam bercerita, kelancaran dalam bercerita, kesesuaiaan isi cerita dengan gambar, dan lafal dan intonasi. Sementara penilaian hasil yaitu: kemampuan menjawab pertanyaan, kelancaran membaca karangan, kerapian tulisan, penggunaan tanda baca. Saat siswa tampil ke depan kelas untuk bercerita masih ada empat orang siswa yang hanya diam tanpa berbicara. Peneliti sebagai guru berusaha memotivasi siswa dengan mengajukan beberapa pertanyaan yang berkaitan dengan gambar agar siswa tersebut dapat menceritakan gambar dengan bahasa sendiri. Apabila jawaban siswa tidak sesuai dengan media gambar maka di sini guru meminta siswa untuk kembali mengamati media gambar seri yang ada dan guru kembali mengajukan pertanyaan yang sama kepada siswa. Untuk lebih meningkatkan keterampilan berbicara siswa, guru meminta siswa untuk menanggapi cerita yang telah diceritakan dengan mengajukan beberapa pertanyaan kepada siswa. Sedangkan kegiatan akhir dilakukan dengan memberikan pesan-pesan moral dan membimbing siswa untuk menyimpulkan pembelajaran.

\section{PEMBAHASAN}

\section{Siklus I}

Pembelajaran diawali dengan kegiatan awal berupa mengkondisikan kelas, menyiapkan sarana dan prasarana untuk proses pembelajaran, dilanjutkan dengan menyampaikan tujuan pembelajaran yaitu agar siswa mampu berbicara melalui media gambar seri. Penyampaian ini sangat penting agar siswa dapat memahami tujuan pembelajaran serta tugas yang akan dilaksanakan nantinya dalam proses pembelajaran. Selajutnya pada kegiatan inti perencanaan pembelajaran diharapkan siswa dapat: (1) menyebutkan peristiwa-peristiwa yang terdapat dalam setiap gambar seri, (2) mengurutkan gambar seri sesuai urutan yang benar, (3) menentukan judul media gambar seri, (4) menceritakan media gambar seri dengan bahasa sendiri. Sedangkan pada kegiatan akhir berupa penyimpulan proses pembelajaran dan pemberian motivasi siswa untuk lebih meningkatkan keterampilan berbicara.

Berdasarkan catatan dilapangan dan diskusi peneliti dengan kepala sekolah sebagai kolaborator atau observer, ternyata siswa memiliki kemampuan dalam hal sebagai berikut: (1) menyebutkan 
Jurnal Penelitian Pendidikan Indonesia

Jurnal Pendidikan Indonesia
Volume 1 Nomor 1 Desember 2015, hlm 27-35

Akses Online: http://jurnal.iicet.org

peristiwa-peristiwa yang terdapat dalam setiap gambar seri, (2) mengurutkan gambar seri sesuai urutan yang benar, (3) menentukan judul media gambar seri, (4) menceritakan media gambar seri dengan bahasa sendiri. Umumnya kemampuan siswa dalam menceritakan media gambar seri meningkat baik dari segi keberanian dalam bercerita, kelancaran dalam bercerita, kesesuaian isi cerita dengan media gambar seri, maupun penggunaan lafal dan intonasi. penyebabnya munculnya kemampuan dari siswa karena penggunaan media gambar seri yang menarik, dekat dengan kehidupan siswa serta pemberian motivasi yang tiada henti dari guru.

Pembelajaran keterampilan berbicara seperti yang telah peneliti lakukan dalam penelitian ini tidak pernah dilaksanakan oleh guru. Guru tidak pernah menggunakan media khususnya media gambar seri yang dekat dengan kehidupan dan dunia anak-anak dalam proses pembelajaran keterampilan berbicara. Hal ini berdampak pada siswa yang tidak tertarik pada pembelajaran keterampilan berbicara yang diberikan karena bersifat abstrak, sehingga keterampilan berbicara siswa tidak dapat meningkat secara optimal. Menurut Piaget, anak usia SD berada dalam perkembangan operasional kongkrit. Siswa lebih cepat menguasai dan faham bila dihadapkan dengan pembelajaran yang bersifat kongkrit dari pada yang bersifat abstrak. Kegiatan akhir pelaksanaan proses pembelajaran berbicara di akhiri dengan menyampaikan pesan-pesan moral dan menyimpukan pembelajaran

Penilaian yang dilakukan pada saat siswa berbicara melalui media gambar seri dengan bahasa sendiri dengan lafal dan intonasi yang sesuai. Penilaian berlangsung secara objektif. Merujuk kepada analisis penelitian siklus I, nilai rata-rata terhadap keterampilan berbicara siswa adalah 11,9. Berdasarkan hasil pengamatan siklus I yang diperoleh masih ada empat belas orang siswa yang memperoleh nilai kurang. Berdasarkan jumlah ketuntasan perorangan maka ketuntasan belajar yang tercapai hanya 53,3\%. Sementara standar ketuntasan belajar adalah sebesar 75\%. Jadi dapat disimpulkan penelitian yang dilakukan pada siklus I masih belum mencapai standar ketuntasan yang diharapkan. Oleh sebab itu peneliti melakukan siklus II dengan harapan akan dapat lebih meningkatkan keterampilan berbicara siswa melalui media gambar seri di kelas IB SDN 18 Batang Anai Kabupaten Padang Pariaman.

\section{Siklus II}

Penggunaan media gambar seri dalam meningkatkan keterampilan berbicara dalam pembelajaran bahasa Indonesia dapat disusun dan diwujudkan dalam bentuk rencana pelaksanaan pembelajaran. Perencanaan pada siklus II pada garis besarnya sama dengan perencanaan siklus I. Perbedaan dapat dilihat dari materi yang akan dibahas yaitu dengan tema pengalaman. Pembelajaran keterampilan berbicara seperti yang telah peneliti lakukan dalam penelitian ini tidak pernah dilaksanakan oleh guru. Guru tidak pernah menggunakan media khususnya media gambar seri yang dekat dengan kehidupan dan dunia anak-anak pada pembelajaran keterampilan berbicara. Akhirnya siswa tidak tertarik pada pembelajaran yang diberikan karena bersifat abstrak sehingga keterampilan berbicara siswa tidak berani dan tidak dapat meningkatkan keterampilan berbicara siswa secara optimal. Siswa lebih cepat menguasai dan faham bila dihadapkan dengan pembelajaran yang bersifat kongkrit dari pada yang bersifat abstrak. Hal ini terlihat dari kemampuan siswa bercerita dengan melihat media gambar seri, dipandu dengan pertanyaan-pertanyaan yang mendukung. Keuntungan pengunaan gambar seri yaitu mudah dimanfaatkan di dalam pembelajaran karena praktis, harganya relatif murah dari jenis-jenis media pembelajaran yang lainnya, dan gambar seri dapat menerjemahkan konsep atau gagasan yang abstrak menjadi lebih realistik (Nana, 1997).

Berdasarkan data-data penilaian proses dan penilaian hasil pada siklus I, nilai rata-rata yang diperoleh siswa adalah $11,9 \%$, dengan empat belas orang siswa yang memiliki jumlah nilai kurang dari 12 dengan persentase ketuntasan 53,3\% sementara target ketuntasan yang ingin dicapai yaitu $75 \%$. Untuk itu hasil refleksi penilaian dari siklus I dilanjutkan ke siklus II, dan hasil penilaian proses dan penilaian hasil dalam keterampilan berbicara melalui medai gambar seri pada siklusII sudah mencapai ketuntasan dengan rata-rata $13,2 \%$, dengan persentase ketuntasan $86 \%$. Dari nilai yang diperoleh pada 
Jurnal Penelitian Pendidikan Indonesia Jurnal Pendidikan Indonesia
Volume 1 Nomor 1 Desember 2015, hlm 27-35

Akses Online: http://jurnal.iicet.org

siklus I dan siklus II mengalami peningkatan. Jadi dapat dikatakan bahwa guru sudah berhasil dalam membelajarkan siswa, dapat dilihat dari hasil penilaiannya.

\section{KESIMPULAN}

Meningkatkan keterampilan berbicara melalui media gambar seri yang telah diselenggarakan pada penelitian ini terbukti sangat efektif dan efesien. Hal ini karena media gambar seri dalam proses pembelajaran dapat berfungsi untuk: 1) mengembangkan kemampuan visual, 2) mengembangkan imajinasi, 3) membantu meningkatkan penguasaan siswa terhadap hal-hal yang abstrak, dan 4) mengembangkan kreatifitas siswa (Basuki, 1991). Meningkatkan keterampilan berbicara dapat dilakukan melalui media gambar seri dengan cara menceritakan media gambar seri dengan bahasa sendiri dengan lafal dan intonasi yang sesuai. Peningkatan keterampilan berbicara siswa juga didukung oleh persiapan perencanaan pelaksanaan pembelajaran berdasarkan kurikulum dan segala komponenkomponen pendukungnya, yang terdiri dari indikator, langkah-langkah pembelajaran, media dan penilaian.

Pelaksanaan proses pembelajaran keterampilan berbicara melalui media gambar seri dimulai dari kegiatan awal, kegiatan inti, dan kegiatan akhir. Selama dalam proses pembelajaran keterampilan berbicara melalui media gambar seri guru juga mengajak siswa bernyanyi dengan menyanyikan lagu yang dikenal dan disukai oleh siswa yang bertujuan untuk mengatasi kejenuhan yang dialami oleh siswa. Penilaian dilakukan baik penilaian proses maupun penilaian hasil selama proses pembelajaran keterampilan berbicara melalui media gambar seri berlangsung. Penilaian ini bertujuan agar dapat memberikan gambaran kemampuan masing-masing siswa, mendiagnosa kesulitan belajar yang dialami siswa, memberikan umpan balik untuk perbaikan proses pembelajaran selanjutnya.

\section{SARAN}

Kepada guru- guru, hendaknya lebih meningkatkan keterampilan berbicara siswa dengan melakukan persiapan pembelajaran yang simaksimal mungkin mulai dari perencanaan RPP, pelaksanaan RPP, dan penilaian yang akan dilakukan. Pelaksanaan proses pembelajaran keterampilan berbicara secara umum dam menceritakan media gambar seri dengan bahasa sendiri secara khususnya, hendaknya menyenangkan bagi siswa. Penyajian pembelajaran lebih divariasi, materi yang diberikan, maupun media yang digunakan. Pelaksanaan pembelajaran keterampilan berbicara yang selama ini dilakukan hanya meminta siswa menceritakan pengalaman dan bertanya jawab, tentu saja hal ini membosankan dan jauh dari jangkauan pemahaman siswa, terutama siswa kelas I, hal ini bisa diatasi dengan menggunkan media karena siswa masih dalam tahap perkembangan operasional kongkrit. Proses penilaian hendaknya dilakukan seobjektif mungkin pada semua siswa. Penilaian hendaknya dilakukan pada saat proses pembelajaran keterampilan berbicara berlangsung maupun pada penilaian hasil dari latihan atau tugas-tugas yang telah dikerjakan oleh siswa. Karena penilaian yang dilakukan dengan baik akan dapat memberikan gambaran kepada guru kemampuan dari masing-masing siswanya untuk dijadikan tolok ukur keberhasilan selama dalam proses pembelajaran itu berlangsung.

\section{DAFTAR RUJUKAN}

Arikunto, Suharsimi, dkk. (2006). Penelitian Tindakan Kelas. Jakarta: Bumi Aksara.

Arsyad, Azhar. (2006). Media Pembelajaran. Jakarta: PT.Raja Grafindo Persada.

Badriyah, Ratu dkk. (2005). Materi dan Pembelajaran Bahas Indonesia Sekolah Dasar. Jakarta: Universitas Terbuka.

Basuki, Wibaya. (1991). Media Pengajaran. Jakarta: Departemen Pendidikan dan Kebudayaan Direktorat Jendral Pendidikan Proyek Pembinaan Tenaga Kependidikan. 
Jurnal Penelitian Pendidikan Indonesia Jurnal Pendidikan Indonesia
Volume 1 Nomor 1 Desember 2015, hlm 27-35

Akses Online: http://jurnal.iicet.org

Depdiknas. (2006). Kurikulum Tingkat Satuan Pendidikan Jenjang Pendidikan Dasar. Jakarta: Depdiknas.

Kridalaksana, Harimurti. (1996). Kamus Besar Bahasa Indonesia. Jakarta: PT. Balai Pustaka.

Lana dan Mustafa G. (1988). Keterampilan Berbicara. Padang: Fakultas Bahasa, Seni dan Sastra Universitas Negeri Padang.

Subana. (1974). Strategi Belajar Mengajar Bahasa Indonesia. Bandung: Pustaka Setia.

Sudiman, Arif. (2003). Media Pendidikan. Jakarta: PT. Raja Grafindo Persada.

Sudjana, Nana dan Ahmad Riva'i. (1997). Media Pengajaran. Bandung: CV. Sinar Bandung.

Tarigan, Hendri Guntur. (1998). Teknik Pengajaran Keterampilan Berbahasa. Bandung: Angkasa. 